University of Nebraska - Lincoln

DigitalCommons@University of Nebraska - Lincoln

Potential for Escape of Live Boll Weevils (Coleoptera:

Curculionidae) into Cottonseed, Motes, and Cleaned Lint at the Cotton Gin

Thomas W. Sappington

USDA-ARS, tsapping@iastate.edu

Alan D. Brashears

USDA-ARS

Megha N. Parajulee

Texas Agricultural Experiment Station

Stanley C. Carroll

Texas Agricultural Experiment Station

Mark D. Arnold

Texas Agricultural Experiment Station

See next page for additional authors

Follow this and additional works at: https://digitalcommons.unl.edu/usdaarsfacpub

Part of the Agricultural Science Commons

Sappington, Thomas W.; Brashears, Alan D.; Parajulee, Megha N.; Carroll, Stanley C.; Arnold, Mark D.; and Baker, Roy V., "Potential for Escape of Live Boll Weevils (Coleoptera: Curculionidae) into Cottonseed, Motes, and Cleaned Lint at the Cotton Gin" (2004). Publications from USDA-ARS / UNL Faculty. 729. https://digitalcommons.unl.edu/usdaarsfacpub/729

This Article is brought to you for free and open access by the U.S. Department of Agriculture: Agricultural Research Service, Lincoln, Nebraska at DigitalCommons@University of Nebraska - Lincoln. It has been accepted for inclusion in Publications from USDA-ARS / UNL Faculty by an authorized administrator of DigitalCommons@University of Nebraska - Lincoln. 
Authors

Thomas W. Sappington, Alan D. Brashears, Megha N. Parajulee, Stanley C. Carroll, Mark D. Arnold, and Roy V. Baker 


\title{
Potential for Escape of Live Boll Weevils (Coleoptera: Curculionidae) into Cottonseed, Motes, and Cleaned Lint at the Cotton Gin
}

\author{
THOMAS W. SAPPINGTON,${ }^{1}$ ALAN D. BRASHEARS, ${ }^{2}$ MEGHA N. PARAJULEE, ${ }^{3}$ \\ STANLEY C. CARROLL,${ }^{3}$ MARK D. ARNOLD,${ }^{3}$ AND ROY V. BAKER ${ }^{2}$
}

USDA-ARS, Kika de la Garza Agricultural Research Center, 2314 E. Highway 83, Weslaco, TX 78596

J. Econ. Entomol. 97(6): 1773-1781 (2004)

\begin{abstract}
Reintroductions of the boll weevil, Anthonomus grandis grandis Boheman, into areas of the United States where it has been eradicated or suppressed are very expensive to mitigate. There is concern that a cotton gin in an eradication zone may serve as a site of boll weevil reintroductions when processing cotton harvested in a neighboring infested zone. Similarly, there is a question whether weevil-free areas can safely import gin products, such as cottonseed and baled lint, from infested areas without risking an introduction. Many countries require fumigation of imported U.S. cotton bales to protect against boll weevil introductions, costing the U.S. cotton industry millions of dollars annually. In previously reported experiments, we quantified the potential for boll weevils to survive passage through precleaning machinery in the gin. In this study, we quantified survival potential of boll weevils passing through the gin stand and segregating into the cottonseed, mote, or lint fractions. We also examined boll weevil survival when passed with ginned lint through a lint cleaner. We present a flow chart of experimentally determined survival potentials of boll weevils passing through the various subprocesses of the gin, from which one can calculate the risk of a live boll weevil reaching any point in the process. Our data show that there is virtually no chance of a boll weevil being segregated alive into the cottonseed or of one surviving in the lint to approach the bale press. Therefore, quarantine or fumigation of cottonseed and cotton bales to guard against boll weevil introductions is unnecessary.
\end{abstract}

KEY WORDS boll weevil, cotton gin, cottonseed, motes, eradication

BoLL WEEVIL, Anthonomus grandis grandis Boheman, is a major pest of cultivated cotton where it still occurs in the Unite States. It is an invasive insect that underwent an explosive range expansion out of southern Mexico after a host shift to cultivated cotton sometime in the mid-19th century (Hunter and Coad 1923, Burke et al. 1986). By the early 1920s, it had spread throughout the southern United States, wreaking havoc with the cotton industry (Haney 2001). Major efforts have been underway since the late 1970s to eradicate the boll weevil from the United States (Smith 1998, Carter et al. 2001), and although this insect has been progressively removed from the southeastern and southwestern states, much remains to be done, especially in Texas and neighboring states (Allen et al. 2003, Grefenstette and El-Lissy 2003). In

\footnotetext{
Mention of trade names or commercial products in this article is solely for the purpose of providing specific information and does not imply recommendation or endorsement by the U.S. Department of Agriculture.

${ }^{1}$ Corresponding author, current address: USDA-ARS-CICGRU, Genetics Laboratory, Iowa State University, Ames, IA 50011 (e-mail: tsapping@iastate.edu).

${ }^{2}$ USDA-ARS-CPPRU, Lubbock, TX 79401.

${ }^{3}$ Texas Agricultural Experiment Station, Lubbock, TX 79403.
}

most states, zones consisting of several counties enter the eradication program after passage of a referendum by local cotton growers (Barker et al. 2001, Brashear and Brumley 2001). Consequently, zones begin the eradication process at different times, creating a geographical patchwork of progress in boll weevil suppression.

There has been concern that boll weevils may be transported to a suppressed or eradicated zone in cotton modules, large free-standing stacks of harvested cotton (Lalor et al. 1994), from a neighboring infested zone and escape the gin in the gin trash, mote bales, cottonseed, or baled lint. The specter of reinfestations and the associated high costs of reeradication create a strong motivation for regulating transport of harvested cotton and gin products out of infested zones (Barker et al. 2001, Dickerson and Haney 2001). Thus, it is imperative to understand and quantify the potential for boll weevil escape from the cotton gin so that future regulatory decisions can target true hazards while minimizing costly and unnecessary precautionary measures (Landolt et al. 1984). Sappington et al. (2004a) concluded from field studies that substantial numbers of boll weevils indeed can be picked up at harvest and packed alive into cotton modules and 
that one can expect live weevils to be fed into the gin with seed cotton harvested from an infested area. In mark-recovery experiments, we have quantified survival potential of boll weevils passed through seed cotton precleaning machinery, dryers operating at different temperatures, and trash fans operated at different fan-tip speeds (Sappington et al. 2004b, c).

In this article, we report results of mark-recovery experiments designed to quantify the potential for boll weevil survival through the gin stand into its three segregated products of cottonseed, motes, and lint. A boll weevil surviving into the lint fraction next passes through one or more lint cleaners (Baker 1978, Mangialardi et al. 1994, Anthony 2000, Holt et al. 2000). Therefore, we tested the potential of boll weevils entering a single saw-type lint cleaner to survive into the cleaned lint or the lint cleaner waste. Finally, we synthesize the results of previous studies (Sappington et al. $2004 \mathrm{a}, \mathrm{b}, \mathrm{c}$ ) with those reported herein to provide overall estimates of boll weevil survival into the various products of the gin.

\section{Materials and Methods}

Experiments were conducted at the USDA-ARS Cotton Ginning Research Laboratory in Lubbock, TX, by using the full-scale research gin at that facility. All adult boll weevils used in the experiments were reared at the USDA-APHIS Mission Plant Protection Center, Mission, TX. Weevil age was not controlled, but it was usually between 1 and $3 \mathrm{wk}$. The experiments consisted of introducing a specified number of marked adults to the ginning, cottonseed conveyance, or lint cleaning process, and determining subsequent survival.

We tested both free adults and adults encapsulated in gelatin capsules (no. 4 size, T.U.B. Enterprises, Almonte, Ontario, Canada), which were baked and dehydrated to make them brittle, as described previously (Sappington et al. 2004a). The capsules were intended to simulate a boll weevil pupal cell, a brittle chamber of tightly packed larval frass in which the adult ecloses from the pupa. Pupal cells containing teneral adults have been found packed inside cotton modules (Sappington et al. 2004b), and they are about the size and shape of cottonseeds, so it is conceivable they might survive to the gin stand and be separated into the seed fraction. It was impossible to collect large numbers of natural pupal cells, so we tested encapuslated adult weevils instead. Although clearly different from natural pupal cells in many respects, the simulated pupal cells afford greater protection to the enclosed adults than the natural cells (T.W.S., unpublished data), so estimates of mortality based on them will be conservative. In all experiments, both capsules and weevils were marked with fluorescent powder (Switzer Brothers, Cleveland, $\mathrm{OH}$ ) to facilitate recovery from the seed cotton under blacklight lamps.

Survival through the Gin Stand. An experiment was conducted to determine survival of marked adult boll weevils, both free and encapsulated, during separation of precleaned seed cotton into lint, seed, and mote fractions at the gin stand. Groups of 300 free adult boll weevils and 100 encapsulated adults per replication were marked with distinct colors of fluorescent powder. Colors were changed for each replication to account for any weevils that were temporarily caught in the seed roll and thus emerged in the lint, seed, or motes of a later replication. In the event, this was not observed. A 136-kg (300-lb) lot of precleaned seed cotton was picked up by the suction telescope and passed again through the cleaning system. As it reached the feeder apron at the gin stand, marked weevils and capsules were sprinkled simultaneously into the seed cotton as evenly as possible. Preliminary tests estimated the time necessary for the $136 \mathrm{~kg}$ of seed cotton to pass over the feeder apron, and the time was counted down aloud to the persons introducing the weevils, so that they could maintain a relatively even rate of sprinkling. The resulting lint fraction was collected in a bin and 10 subsamples of $\approx 1000 \mathrm{~g}$ each were taken from upper, middle, and lower sections of the lint pile. The subsamples of lint, as well as all resulting seeds and motes, were searched under blacklight lamps for live and dead boll weevils, and for intact or nearly intact capsules. Many weevil parts were observed, but only a boll weevil with at least one-half of the body present was counted as a dead weevil. Live free weevils were placed together in a petri dish containing a cotton wick soaked in water, whereas weevils recovered alive in capsules, were returned to the capsule and placed together in a petri dish without water. All weevils were examined after $24 \mathrm{~h}$ for survival. Twenty marked free adults and 20 marked weevils in capsules were held in the laboratory at room temperature in a petri dish as controls for mortality. Free adult controls were provided with a cotton wick soaked in water. Mortality among controls was low in all cases, so the data are not presented. The experiment was replicated three times.

Survival through the Cottonseed Conveyance System. Mortality occurs in the separation process itself at the gin stand, but live weevils segregated into the seed fraction also could be killed during transit to the seed bin. Thus, we conducted an experiment to determine the potential of free and encapsulated boll weevils that survive separation with the seed to further survive the conveyance system from the gin stand to the seed bin. Three-hundred free adult boll weevils and 100 encapsulated adults per replication were marked and uniformly distributed into $22.7 \mathrm{~kg}$ (50 lb) of cottonseed spread evenly along a $3-\mathrm{m}$ (10-ft) conveyor belt. The weevil-seeded cottonseed was dumped into a bin and then fed into the seed conveyance system, consisting of 40-cm-diameter piping, by using a suction telescope. The seed was collected at the seed bin outlet, through which it is normally dropped into a receiving truck. All seed thus retrieved was inspected under blacklight for dead and surviving weevils. Continued weevil survival to $24 \mathrm{~h}$ was checked as described above. The experiment was replicated three times.

Survival through a Lint Cleaner. An experiment was conducted to determine survival of marked adult 
boll weevils, both free and encapsulated, in lint and lint-cleaner waste fractions after passing through a single saw-type lint cleaner. Three-hundred free adult boll weevils and 100 encapsulated adults per replication were marked with distinct colors of fluorescent powder. Preliminary trials established the amount of time necessary for $136 \mathrm{~kg}(300 \mathrm{lb})$ of ginned cotton to pass an opened panel in the ductwork located between the gin stand and the lint cleaner. During the experiment, free and encapsulated weevils were simultaneously sprinkled as evenly as possible into the seed cotton as it passed the open panel while the time was counted down aloud. The lint was collected at the bale press, where it was lightly formed into a loose stack at a pressure previously determined to cause no mortality (Brashears et al. 2002). The stack was divided into 10 layers. Each layer was parted in the center, and $\approx 1000 \mathrm{~g}$ of lint was subsampled, drawing evenly from top to bottom at the part. This procedure was intended to reduce any variation caused by temporally uneven sprinkling of the weevils into the seed cotton. The experiment was replicated three times. In addition, a control run was conducted in which weevils were sprinkled into the lint but the lint was not cleaned. It was collected at the bale press and subsamples were taken and processed as described above. The control provided an estimate of efficiency in recovering marked weevils from the lint subsamples.

Analysis. In some experiments, no boll weevils were recovered that survived to $24 \mathrm{~h}$ in any of the replicated runs. Although we have no evidence that survival is possible in those cases, we cannot conclude that it is impossible, because increasing the sample size might eventually result in a survivor (McArdle 1990; Venette et al. 2002; Sappington et al. 2004b, c). Instead, we calculated the upper $95 \%$ confidence limit $\left(p_{u}\right)$ for the observed zero recovery based on the number of insects tested $(n)$, by using the following formula:

$$
p_{u}=1-(1-\mathrm{C})^{1 / n}
$$

where $\mathrm{C}$ is the desired confidence level (in this case, 0.95) (Couey and Chew 1986, Venette et al. 2002). All replications were pooled when determining $n$ (Sappington et al. 2004b).

\section{Results}

Survival through the Gin Stand. The 136.2-kg (300$\mathrm{lb})$ lots of cleaned seed cotton fed into the gin stand yielded 79.4-83.1 kg (175-183 lb) of cottonseed, 0.81$0.89 \mathrm{~kg}(1.8-2.0 \mathrm{lb})$ of motes, and 46.3-50.8 kg (102$112 \mathrm{lb}$ ) of lint. Only an estimated $11.6 \pm 3.28 \%$ of the free adult boll weevils entering the gin stand were recovered dead or alive in the cottonseed, motes, and lint (corrected for the size of the subsamples) combined (Tables 1 and 2), indicating that most weevil bodies were completely destroyed by the mechanical separation processes taking place at the gin stand. Of the weevils recovered, $21 \pm 3.2 \%$ were segregated into the cottonseed, $10 \pm 2.0 \%$ into the mote, and $69 \pm 1.3 \%$ into the lint fractions. Two live boll weevils were found among the three lots of cottonseed, and only

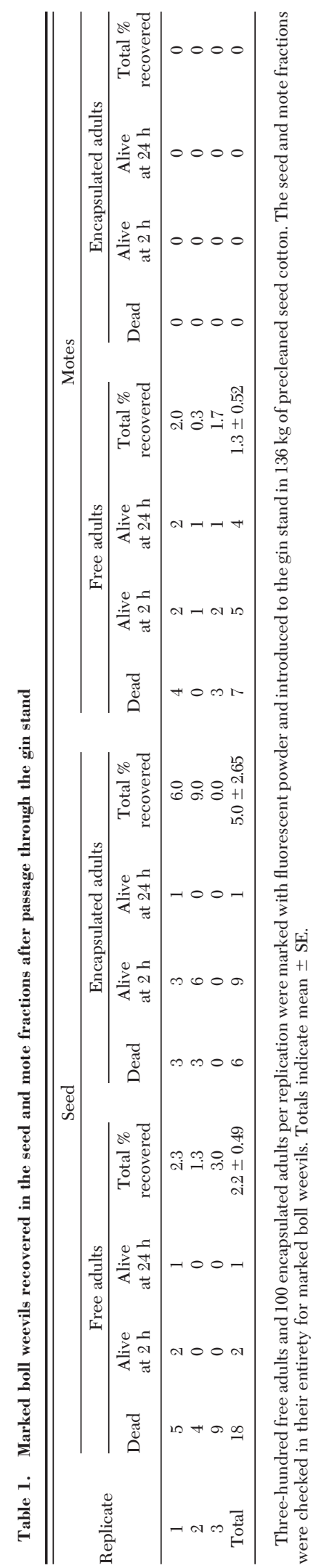


Table 2. Marked boll weevils recovered in the lint fraction after passage through the gin stand

\begin{tabular}{|c|c|c|c|c|c|c|c|c|c|c|c|}
\hline \multirow[b]{2}{*}{ Replicate } & \multirow{2}{*}{$\begin{array}{c}\% \text { lint } \\
\text { subsampled }\end{array}$} & \multicolumn{5}{|c|}{ Free adults } & \multirow[b]{2}{*}{$\begin{array}{l}\text { Expected } \\
\text { recovery }\end{array}$} & \multicolumn{4}{|c|}{ Encapsulated adults } \\
\hline & & $\begin{array}{l}\text { Expected } \\
\text { recovery }\end{array}$ & Dead & $\begin{array}{l}\text { Alive } \\
\text { at } 2 \mathrm{~h}\end{array}$ & $\begin{array}{c}\text { Alive } \\
\text { at } 24 \mathrm{~h}\end{array}$ & $\begin{array}{l}p_{u} \text { alive } \\
\text { at } 24 \mathrm{~h}^{b}\end{array}$ & & Dead & $\begin{array}{l}\text { Alive } \\
\text { at } 2 \mathrm{~h}\end{array}$ & $\begin{array}{c}\text { Alive } \\
\text { at } 24 \mathrm{~h}\end{array}$ & $\begin{array}{l}p_{u} \text { alive } \\
\text { at } 24 \mathrm{~h}^{b}\end{array}$ \\
\hline 1 & 21.7 & 65.1 & 7 & 0 & 0 & & 21.7 & 0 & 0 & 0 & \\
\hline 2 & 19.7 & 59.1 & 1 & 1 & 0 & & 19.7 & 0 & 0 & 0 & \\
\hline 3 & 20.1 & 60.3 & 6 & 0 & 0 & & 20.1 & 1 & 0 & 0 & \\
\hline Total & & 184.5 & 14 & 1 & 0 & 0.0155 & 61.5 & 1 & 0 & 0 & 0.0452 \\
\hline
\end{tabular}

Three-hundred free adults and 100 encapsulated adults per replication were marked with fluorescent powder and introduced to the gin stand in $136 \mathrm{~kg}$ of precleaned seed cotton.

${ }^{a}$ Calculated based on proportional weight of the cotton subsampled and assuming that $100 \%$ of the boll weevils were segregated into the ginned lint fraction and that $100 \%$ of all boll weevil bodies passing through the gin stand remained intact.

${ }^{b}$ Upper confidence limit $(95 \%)$ for zero recovery of live adults surviving $24 \mathrm{~h}$, calculated as $p_{u}=1-(1-0.95)^{1 / n}$ using expected recovery as $n$.

one lived to $24 \mathrm{~h}$ (Table 1), indicating a mean survival rate into the seed fraction of $0.11 \pm 0.11 \%$ among weevils entering the gin stand after precleaning. Five live weevils were found among the three lots of motes, and four of those lived to $24 \mathrm{~h}$ (Table 1), indicating a survival rate into the mote fraction of $0.4 \pm 0.11 \%$ among weevils entering the gin stand after precleaning.

One boll weevil was recovered alive within $2 \mathrm{~h}$ after passage through the gin stand into the lint fraction, but it was severely damaged and did not survive to $24 \mathrm{~h}$ (Table 2). The upper $95 \%$ confidence limit $\left(p_{u}\right)$ for the observed zero recovery was calculated based solely on sample size by equation 1 as 0.0161 . However, $3.5 \%$ of the introduced weevils were accounted for in the seed and mote fractions (Table 1 ), so the initial $p_{u}$ must be multiplied by the proportion of weevils unaccounted for $(0.965)$, giving a corrected $p_{u}$ of 0.0155 . In other words, we are $95 \%$ certain that the chances of a boll weevil surviving for $24 \mathrm{~h}$ after passage through the gin stand into the cleaned lint lies somewhere in the range of $0-1.55 \%$.

Of the encapsulated boll weevils introduced in the three runs, only an estimated $6.6 \%$ were recovered dead or alive in the seed, motes, and lint combined (Tables 1 and 2), again indicating that most gelatin capsules and the weevils therein were destroyed at the gin stand. Of those recovered, $75.6 \%$ were in the cottonseed, $24.5 \%$ were in the lint, and none were found in the motes. Of the nine live encapsulated weevils recovered in the seed fraction, only one survived to $24 \mathrm{~h}$ (Table 1). No live encapsulated boll weevils were recovered from the lint (Table 2 ). The corrected $p_{u}$ values for the zero recoveries in the motes and lint were 0.0280 and 0.0452 , respectively.

Survival through the Cottonseed Conveyance System. Any mortality of boll weevils occurring during passage through the seed conveyance system presum- ably is caused by physical trauma associated with striking the walls of the pipes at high speed, especially at elbows. Because there are no fans or other mechanical devices through which the seed passes after separation at the gin stand, it was anticipated that survival would be high. Average immediate survival was indeed high for both free adults $(75.0 \pm 2.17 \%)$ and those in gelatin capsules $(90 \pm 4.35 \%)$ (Table 3 ). However, many of these weevils were fatally damaged, as evidenced by continued survival to $24 \mathrm{~h}$, which was only $30.4 \pm$ $4.01 \%$ for free adults and $35.3 \pm 6.49 \%$ for encapsulated adults (Table 3 ). Only a small percentage of boll weevils introduced were not recovered either dead or alive (Table 3).

Survival through a Lint Cleaner. In an initial control run, boll weevils were introduced into ginned lint which was subsampled after passage to the bale press without the lint cleaning system operating. We expected to recover 61 of the 300 introduced free adult weevils based on the percentage of ginned lint that was subsampled and assuming even distribution of the weevils throughout the lint (Table 4). We recovered 60 boll weevils, indicating that few if any free adults would get lost in the long system of ductwork in the experimental runs, and that we would overlook few weevils present in subsamples of cleaned lint. We expected to recover 20 of the 100 introduced weevilcontaining gelatin capsules in the lint of the control run, but found only 10 (Table 4 ). The reason for the low recovery of capsules is unknown. Because capsules are relatively easy to detect in the lint samples, it is unlikely that they were present but missed. It is possible that the missing capsules became lodged in the system ductwork.

When exposed to the operating lint cleaner, $48.7 \pm$ 6.55 and $40.7 \pm 9.77 \%$ of the introduced free and encapsulated adults were recovered in the lint cleaner waste fraction, respectively, most of which were dead

Table 3. Recovery (mean \pm SE) of marked boll weevils transported through the cottonseed conveyance system at the cotton gin

\begin{tabular}{lcccc}
\hline \hline Boll weevils & $\begin{array}{c}\text { No. } \\
\text { replicates }\end{array}$ & Dead & Alive at 2 h & $\begin{array}{c}\% \text { recovered } \\
(\text { dead }+ \text { alive })\end{array}$ \\
\hline Free & 3 & $55.3 \pm 3.76$ & $225.0 \pm 6.51$ & $91.3 \pm 12.03$ \\
Encapsulated & 3 & $19.0 \pm 6.33$ & $90.0 \pm 4.35$ & $35.3 \pm 6.49$ \\
\hline
\end{tabular}

Three-hundred free adults and 100 encapsulated adults per replication were marked with fluorescent powder and conveyed with $22.7 \mathrm{~kg}$ of cottonseed to the seed bin. 
Table 4. Marked boll weevils recovered in the lint after passage through one saw-type lint cleaner in the cotton gin

\begin{tabular}{|c|c|c|c|c|c|c|c|c|c|c|c|}
\hline \multirow[b]{2}{*}{ Replicate } & \multirow{2}{*}{$\begin{array}{c}\% \text { of lint } \\
\text { subsampled }\end{array}$} & \multicolumn{5}{|c|}{ Free adults } & \multicolumn{5}{|c|}{ Encapsulated adults } \\
\hline & & $\begin{array}{l}\text { Expected } \\
\text { recovery }\end{array}$ & Dead & $\begin{array}{l}\text { Alive } \\
\text { at } 2 \mathrm{~h}\end{array}$ & $\begin{array}{l}\text { Alive } \\
\text { at } 24 \mathrm{~h}\end{array}$ & $\begin{array}{l}p_{u} \text { alive } \\
\text { at } 24 \mathrm{~h}^{b}\end{array}$ & $\begin{array}{l}\text { Expected } \\
\text { recovery }\end{array}$ & Dead & $\begin{array}{l}\text { Alive } \\
\text { at } 2 \mathrm{~h}\end{array}$ & $\begin{array}{c}\text { Alive } \\
\text { at } 24 \mathrm{~h}\end{array}$ & $\begin{array}{l}p_{u} \text { alive } \\
\text { at } 24 \mathrm{~h}^{b}\end{array}$ \\
\hline $\mathrm{C}$ & 20.4 & 61.2 & 3 & 57 & 52 & & 20.4 & 0 & 10 & 10 & \\
\hline 1 & 21.5 & 64.5 & 0 & 0 & 0 & & 21.5 & 0 & 0 & 0 & \\
\hline 2 & 21.1 & 63.3 & 4 & 0 & 0 & & 21.1 & 0 & 0 & 0 & \\
\hline 3 & 21.2 & 63.6 & 3 & 0 & 0 & & 21.2 & 1 & 1 & 0 & \\
\hline $\begin{array}{l}\text { Treatment } \\
\text { total }\end{array}$ & & 191.4 & 7 & 0 & 0 & 0.0080 & 63.8 & 1 & 1 & 0 & 0.0272 \\
\hline
\end{tabular}

Groups of 300 free adults and 100 encapsulated adults marked with fluorescent powder were mixed into $136 \mathrm{~kg}$ of ginned cotton lint and introduced to the lint cleaner. Controls (C) represent weevils and capsules introduced to ginned lint and collected at the bale press, but not passing through an operating lint cleaner.

${ }^{a}$ Calculated based on proportional weight of the cotton subsampled and assuming that $100 \%$ of the boll weevils were segregated into the cleaned lint fraction and that $100 \%$ of all boll weevil bodies passing through the lint cleaner remained intact.

${ }^{b}$ Upper confidence limit $(95 \%)$ for observed zero recovery of live adults surviving $24 \mathrm{~h}$, calculated as $p_{u}=\left[1-(1-0.95)^{1 / n}\right] U$ using total expected recovery as $n ; U$ is the mean proportion of introduced boll weevils not recovered in the lint mote fraction (see Table 5 ).

(Table 5). The probability of a boll weevil in ginned lint escaping a lint cleaner alive into the waste fraction and living at least $24 \mathrm{~h}$ was $1.2 \pm 0.48 \%$ for free adults and $1.0 \pm 0.58 \%$ for encapsulated adults. Many weevil parts were observed in the waste fraction, suggesting that the bodies of most unrecovered weevils were destroyed during separation from the lint. No free adults were found alive in the cleaned lint and only seven dead weevils were recovered (Table 4). A total of one dead and one live encapsulated weevil was found, but the live weevil was damaged and did not live to $24 \mathrm{~h}$ (Table 4 ). Thus, we found no evidence that boll weevils can survive passage through a lint cleaner into the lint fraction. The $p_{u}$ calculated based solely on sample size for the observed zero rate of recovery of free adults is 0.0155 . However, because experiments showed that on average at least $48.7 \%$ of the introduced boll weevils were segregated into the lint cleaner waste fraction, the initial $p_{u}$ must be multiplied by the proportion unaccounted for $(0.513)$, yielding a corrected $p_{u}$ of 0.0080 (Table 4 ).

\section{Discussion}

One hundred years ago, Hunter (1904) introduced marked boll weevils to the gin stand and recovered high percentages of survivors in the cottonseed, motes, and ginned lint. He concluded that gins were contributing to the spread of boll weevils across the Cotton Belt by processing infested cotton. Although modern gin stands are based on the same mechanical principles used in the older gins, they use more closely spaced saws that operate at higher speeds, and we expected boll weevil mortality to be much higher than what Hunter observed. Hughs et al. (2002) introduced 1000 marked boll weevils in each of three replications into cleaned seed cotton entering the gin stand and continuing through a single lint cleaner. No surviving weevils were recovered in any of the $\approx 32-\mathrm{kg}$ lots of ginned and cleaned lint. They did recover a nearly whole, but dead and damaged weevil in one of the lint lots. In our experiments, we found no evidence of boll weevil survival in lint after passage through the gin stand alone. Thus, it is clear that the probability of a boll weevil entering the gin stand and surviving intact in ginned lint is close to zero. Hughs et al. (2002) indicated that some live weevils were recovered in the cottonseed, but they did not report how many. Our results indicated that $0.11 \%$ of the boll weevils introduced to the gin stand were recovered alive in the cottonseed. Based on data of mortality caused by the seed conveyance system, the mean mortality of boll weevils segregated into the cottonseed fraction that was caused by the ginning process alone was $99.64 \%$. Although Hughs et al. (2002) recovered no live weevils in the mote fraction, several survivors were reclaimed in our experiments (Table 1).

After removal of the cottonseed at the gin stand, motes and small foreign matter particles must be removed from the lint by a lint cleaner. A saw-type lint cleaner also serves to blend the cotton fibers (Dunn et al. 2002), and this is the most common type of lint

Table 5. Marked boll weevils recovered in the mote fraction after passage through one saw-type lint cleaner in the cotton gin

\begin{tabular}{|c|c|c|c|c|c|c|c|c|c|}
\hline \multirow[b]{2}{*}{ Replicate } & \multirow{2}{*}{$\begin{array}{c}\text { Motes } \\
\text { generated } \\
(\mathrm{kg})\end{array}$} & \multicolumn{4}{|c|}{ Free adults } & \multicolumn{4}{|c|}{ Encapsulated adults } \\
\hline & & Dead & $\begin{array}{c}\text { Alive at } \\
2 \mathrm{~h}\end{array}$ & $\begin{array}{c}\text { Alive at } \\
24 \mathrm{~h}\end{array}$ & $\begin{array}{c}\% \text { total } \\
\text { recovered }\end{array}$ & Dead & $\begin{array}{l}\text { Alive at } \\
2 \mathrm{~h}\end{array}$ & $\begin{array}{c}\text { Alive at } \\
24 \mathrm{~h}\end{array}$ & $\begin{array}{c}\% \text { total } \\
\text { recovered }\end{array}$ \\
\hline 1 & 2.0 & 92 & 20 & 4 & 37.3 & 17 & 5 & 2 & 22.0 \\
\hline 2 & 2.1 & 155 & 25 & 6 & 60.0 & 38 & 7 & 1 & 45.0 \\
\hline 3 & 1.8 & 136 & 10 & 1 & 48.7 & 55 & 0 & 0 & 55.0 \\
\hline Mean $\pm \mathrm{SE}$ & & & & & $48.7 \pm 6.55$ & & & & $40.7 \pm 9.77$ \\
\hline
\end{tabular}

Free adults (300 per replication) and encapsulated adults (100 per replication) marked with fluorescent powder were mixed into 136 kg of ginned cotton lint and introduced to the lint cleaner. The mote fraction generated by the cleaning process was checked in its entirety for boll weevils. 


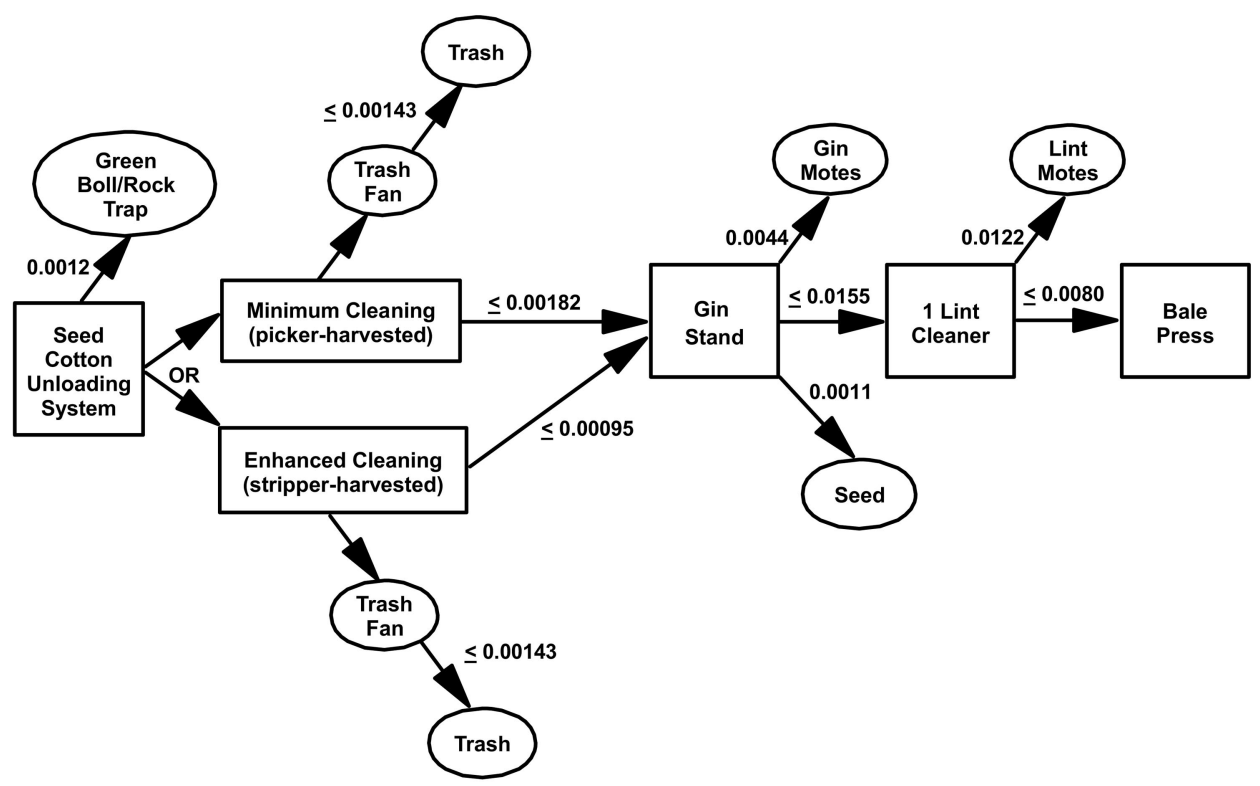

Fig. 1. Flow chart of cotton through a cotton gin (with dryers unheated), from entry into the gin plant through approach to the bale press, with product outputs indicated. Proportions indicate experimentally determined 24-h survival potentials of free adult boll weevils from the point in the ginning process marked by the base of an arrow to the next stage or output product at the tip of the arrow. A percentage preceded by " $\leq$ " represents the $p_{u}$ (95\% upper confidence limit) calculated for an observed zero recovery of marked adults surviving $24 \mathrm{~h}$. For green boll/rock trap, and minimum and enhanced seed cotton cleaning estimates, see Sappington et al. (2004b); for trash fan estimates, see Sappington et al. (2004c).

cleaner used in modern gins (Mangialardi et al. 1994). Robertson et al. (1963) found that no pink bollworm larvae survived passage through a saw-type lint cleaner. Similarly, we found no boll weevil survivors in the lint after passage through a saw-type lint cleaner. Although there is evidence that net profit often is maximized by using only a single lint cleaner (Bennett et al. 1997, Nelson et al. 1999), passing the lint through two cleaners is the ginning industry norm (Mangialardi et al. 1994, Nelson et al. 1999, Anthony 2000), and even three lint cleaners are occasionally used (Ethridge et al. 1995). Thus, the chances of a boll weevil surviving lint cleaning in most gins will be much closer to zero than to the $p_{u}$ calculated for our sample size.

We showed in previous work that live boll weevils can be expected to enter the gin plant in infested seed cotton, sometimes in large numbers (Sappington et al. 2004a). However, our mark-recovery experiments have provided no evidence that a boll weevil can survive precleaning machinery to approach the gin stand in the seed cotton (Sappington et al. 2004b), the gin stand to approach the first lint cleaner, or the first lint cleaner to approach a second lint cleaner or the bale press. However, because of limitations imposed by sample size we cannot conclude that survival of any of these processes is impossible (McArdle 1990; Venette et al. 2002; Sappington et al. 2004b, c). Such uncertainties are a common element of quarantine problems, and quantifying the uncertainty is critical for policy formulation (Brown 2003). Our approach has been to calculate the upper 95\% CL ( $p_{u}$ values) for observed rates of zero recovery of live boll weevils (Couey and Chew 1986; Venette et al. 2002; Sappington et al. $2004 \mathrm{~b}, \mathrm{c}$ ). The $p_{u}$ can be considered the worst-case survival potential for a given ginning subprocess. The cumulative probability of boll weevil survival to any point in the ginning process, including products of the gin, can be determined by multiplying the respective probabilities of surviving the preceding subprocesses, using calculated $p_{u}$ values in cases where no survivors were recovered (Fig. 1).

Boll Weevil Survival in Cottonseed. Approximately 4.5-6 million metric tons of cottonseed are produced each year in the United States, $98 \%$ of which is used for oil production or cattle feed (Willcutt and Mayfield 1994). Recently, there has been concern in several states regarding the risk of transporting live boll weevils in cottonseed from gins in infested areas to weevilfree areas, and we now have data from which that risk can be quantified (Fig. 1). The probability of boll weevil survival into the cottonseed is a product of sequential survival through the seed cotton precleaning process and the separation process at the gin stand. Thus, multiplying the $p_{u}$ for survival of a minimal seed cotton precleaning process with no added heat in the dryers $(0.00182$; Sappington et al. 2004b) by a 0.0011 rate of survival observed for boll weevils entering the gin stand and segregating into the seed fraction (Table 1; Fig. 1), indicates that the probability a boll weevil entering the gin plant will escape alive into the cottonseed is no greater than $2.002 \times 10^{-6}$. Thus, the minimum mortality rate inflicted on boll weevils segregating into the cottonseed $(99.9998 \%)$ is greater 
than the probit 9 level $(99.9968 \%)$ traditionally required for quarantine security (Landolt et al. 1984, Hughes 2003). Given that not even any dead boll weevils were recovered intact from the precleaning experiments (Sappington et al. 2004b), the true mortality rate is likely much greater than that calculated based on the $p_{u}$ value. In addition, passage through enhanced precleaning machinery sequences used for stripper-harvested cotton and/ or through heated dryers will increase mortality as well (Sappington et al. 2004b).

As Landolt et al. (1984) pointed out, the effectiveness of a probit 9 mortality rate attributed to treatment of a commodity in preventing introduction of a pest depends on the initial infestation rate. In a survey of cotton modules from three boll weevil-infested regions of Texas over $2 \mathrm{yr}$, mean estimates of boll weevils packed alive into modules ranged from 341 to 7,219 (Sappington et al. 2004a). Survival of boll weevils within a module decreases over time (Sappington et al. 2004a), but in the following calculations we assume $100 \%$ survival into the gin plant. With an initial heavy infestation of 7,219 boll weevils per module, and a $2.002 \times 10^{-6}$ rate of survival under the most lenient ginning and stringent statistical scenarios, the number of live boll weevils segregating into the cottonseed per module is calculated to be 0.0145 , or one weevil per 69 heavily infested modules. Males are unimportant in the context of potential boll weevil reinfestations (Landolt et al. 1984, Baker et al. 1990, Hughes 2003). Assuming a 1:1 sex ratio, one would expect one female per 138 heavily-infested modules to escape alive into the cottonseed. If one assumes $363 \mathrm{~kg}(800 \mathrm{lb})$ of cottonseed produced per bale (Willcutt and Mayfield 1994) and 12 bales per module (Lalor et al. 1994), this translates to $\approx 1$ live female per $600 \mathrm{mT}$ of cottonseed under worst-case conditions.

We emphasize that the calculated survival rate is probably a gross overestimate of the actual survival that can be expected, for the reasons explained above. Furthermore, initial infestation levels in modules of seed cotton usually will be lower than that used in the calculations (Sappington et al. 2004a), will be greatly reduced in cotton harvested in areas where eradication is in progress, and will be zero in cotton harvested in areas of the United States where eradication has been completed. In addition, a successful reinfestation would require that any female boll weevil surviving into the seed must already be mated and continue to survive for a prolonged period after cottonseed packaging, under whatever temperatures the cottonseed experiences during transport and storage. This may be possible if the female is in diapause and exposure temperatures are not extreme, but a reproductive or recently emerged female can be expected to live only a few days in the absence of food. A diapausing, mated boll weevil female in good enough physical condition to disperse from an opened package of cottonseed at an oil mill or feed lot would have to successfully escape any secondary enclosure (building) and locate nearby cultivated cotton at an appropriate phenological stage to support diet-induced termination of diapause
(Spurgeon and Raulston 1998, Spurgeon et al. 2003), oviposition, and successful development of offspring, or else to locate suitable overwintering habitat in which to continue diapause. Given these considerations and our experimental findings of extremely low survival potential to the seed bin in the first place, it is clear that quarantine or fumigation of cottonseed as a precaution against boll weevil introductions is unnecessary.

Boll Weevil Survival to the Bale Press. Importers of U.S. cotton often require fumigation of bales to kill boll weevils, costing the U.S. cotton industry millions of dollars each year. The probability of boll weevils surviving in lint to the bale press can be calculated in the same way as described for survival to the seed bin by using the sequential probabilities presented in Fig. 1. Multiplying the $p_{u}$ values for survival of minimal seed cotton cleaning, survival through the gin stand, and survival through one lint cleaner indicates that the probability of a boll weevil surviving in the lint to approach the bale press lies somewhere in the range of $0-2.26 \times 10^{-7}$. With an initial heavy infestation rate of 7,219 boll weevils per module (Sappington et al. 2004a), and under worst-case machine-sequence and statistical-confidence scenarios, one could expect one female boll weevil surviving to approach the bale press for every 14,731 bales produced.

Again, we emphasize that actual boll weevil survival potential is expected to be profoundly less than the product of the $p_{u}$ values, based on our observations of the level of destruction of insect bodies in each of the subprocesses leading to the bale press. It will be reduced even further in gins by using enhanced precleaning machinery sequences for stripper-harvested cotton (Sappington et al. 2004b), heating in one or two dryers (Sappington et al. 2004b), and/ or passage of the lint through more than one lint cleaner, all of which are much more common ginning scenarios than the highest risk machinery sequence to which we limited our calculations. In work to be published elsewhere (see Brashears et al. 2002 and Hughs et al. 2002 for preliminary reports), it has been demonstrated that any boll weevils making it alive to the bale press cannot survive the pressures encountered in a normalweight bale during tie-out to universal density. The results reported here indicate that there is virtually no chance of a boll weevil surviving to the bale press in the first place, so even underweight bales pose no threat of harboring this insect. Thus, restricting transport of cotton bales within the United States as a precaution against reintroductions of boll weevils to eradication zones is unnecessary. Similarly, the requirements of importing countries for fumigation of U.S. bales can be lifted safely without risking boll weevil introductions.

\section{Acknowledgments}

We thank Latha Bommireddy, Veronica Cardoza, Jimmy Castro, Andy Cranmer, Valentina Greenberg, Lanthia Jones, Anand Sapkota, R. B. Shrestha, Bill Turner, and Orlando Zamora for technical assistance. Thank you to Leeda Wood 
for providing us with laboratory-reared boll weevils. Funding was provided in part by grants IPM01-023 to R.V.B. and T.W.S., and IPM02-004 to T.W.S. and A.D.B. from the Texas Department of Agriculture.

\section{References Cited}

Allen, C. T., L. E. Smith, L. W. Patton, and R. O. Newman. 2003. Status of boll weevil eradication in Texas, pp. 1340 1345. In Proceedings of the Beltwide Cotton Conferences, 6-10 January, Nashville, TN. National Cotton Council, Memphis, TN.

Anthony, W. S. 2000. Methods to reduce lint cleaner waste and damage. Trans. Am. Soc. Agric. Eng. 43: 221-229.

Baker, R. T., J. M. Cowley, D. S. Harte, and E. R. Frampton. 1990. Development of a maximum pest limit for fruit flies (Diptera: Tephritidae) in produce imported into New Zealand. J. Econ. Entomol. 83: 13-17.

Baker, R. V. 1978. Performance characteristics of saw-type lint cleaners. Trans. Am. Soc. Agric. Eng. 21: 1081-1087, 1091.

Barker, B., C. H. Parker, A. G. King, and W. Anderson. 2001. What's required to finish the job and protect our investment?, pp. 509-522. In W. A. Dickerson, A. L. Brashear, J. T. Brumley, F. L. Carter, W. J. Grefenstette, and F. A. Harris [eds.], Boll weevil eradication in the United States through 1999. The Cotton Foundation Publisher, Memphis, TN.

Bennett, B. K., S. K. Misra, and G. Barker. 1997. Lint cleaning stripper-harvested cotton for maximizing producer net returns. Appl. Eng. Agric. 13: 459-463.

Brashear, A. L., and J. Brumley. 2001. The evolution of program management, U.S. Dep. Agric./grower responsibilities and funding in the Southeastern Boll Weevil Eradication Program, pp. 77-100. In W. A. Dickerson, A. L. Brashear, J. T. Brumley, F. L. Carter, W. J. Grefenstette, and F. A. Harris [eds.], Boll weevil eradication in the United States through 1999. The Cotton Foundation Publisher, Memphis, TN.

Brashears, A. D., R. V. Baker, T. W. Sappington, S. C. Carroll, M. D. Arnold, and M. N. Parajulee. 2002. Boll weevil survival in baled lint, 5 pp. In Proceedings of the Beltwide Cotton Conferences, (CD), 8-12 January, Atlanta, GA. National Cotton Council, Memphis, TN.

Brown, L. G. 2003. Analyzing positive finds with explicit uncertainty. Plant Health Progress. Online, doi:10.1094/ PHP-2003-1113-04-RV.

Burke, H. R., W. E. Clark, J. R. Cate, and P. A. Fryxell. 1986. Origin and dispersal of the boll weevil. Bull. Entomol. Soc. Am. 32: 228-238.

Carter, F. L., T. C. Nelson, A. G. Jordan, and J. R. Smith. 2001. U.S. cotton declares war on the boll weevil, pp. 25-54. In W. A. Dickerson, A. L. Brashear, J. T. Brumley, F. L. Carter, W. J. Grefenstette, and F. A. Harris [eds.], Boll weevil eradication in the United States through 1999. The Cotton Foundation Publisher, Memphis, TN

Couey, H. M., and V. Chew. 1986. Confidence limits and sample size in quarantine research. J. Econ. Entomol. 79: 887-890.

Dickerson, W. A., and P. B. Haney. 2001. A review and discussion of regulatory issues, pp. 137-156. In W. A. Dickerson, A. L. Brashear, J. T. Brumley, F. L. Carter, W. J. Grefenstette, and F. A. Harris [eds.], Boll weevil eradication in the United States through 1999. The Cotton Foundation Publisher, Memphis, TN.

Dunn, T. A., S. K. Misra, G. L. Barker, and R. V. Baker. 2002. Predicting lint cleaner efficiency and fiber quality char- acteristics in cotton ginning. Appl. Eng. Agric. 18: 141146.

Ethridge, D. E., G. L. Barker, and D. L. Bergan. 1995. Maximizing net returns to gin lint cleaning of stripper-harvested cotton. Appl. Eng. Agric. 11: 7-11.

Grefenstette, B., and O. El-Lissy. 2003. Boll weevil eradication update, pp. 131-141. In Proceedings of the Beltwide Cotton Conferences, 6-10 January, Nashville, TN. National Cotton Council, Memphis, TN.

Haney, P. B. 2001. The cotton boll weevil in the United States: impact on cotton production and the people of the Cotton Belt, pp. 7-24. In W. A. Dickerson, A. L. Brashear, J. T. Brumley, F. L. Carter, W. J. Grefenstette, and F. A. Harris [eds.], Boll weevil eradication in the United States through 1999. The Cotton Foundation Publisher, Memphis, TN.

Holt, G. A., G. L. Barker, R. V. Baker, and A. Brashears. 2000. Characterization of cotton gin byproducts produced by various machinery groups used in the ginning operation. Trans. Am. Soc. Agric. Eng. 43: 1393-1400.

Hughes, G. 2003. The maximum pest limit concept explained. Plant Health Progress. Online, doi:10.1094/ PHP2003-1113-05-RV.

Hughs, S. E., C. B. Armijo, and R. T. Staten. 2002. Boll weevil survival in the ginning system, pp. 1-5. In Proceedings of the Beltwide Cotton Conferences, (CD), 8-12 January, Atlanta, GA. National Cotton Council, Memphis, TN.

Hunter, W. D. 1904. Controlling the boll weevil in cotton seed and at ginneries. USDA, Farmers' Bull. No. 209.

Hunter, W. D., and B. R. Coad. 1923. The boll-weevil problem. USDA, Farmers' Bull. 1329.

Lalor, W. F., M. H. Willcutt, and R. G. Curley. 1994. Seed cotton storage and handling, pp. 16-25. In W. S. Anthony and W. D. Mayfield [eds.], Cotton ginners handbook. USDA, Agricultural Handbook 503.

Landolt, P. J., D. L. Chambers, and V. Chew. 1984. Alternative to the use of probit 9 mortality as a criterion for quarantine treatments of fruit fly (Diptera: Tephritidae)infested fruit. J. Econ. Entomol. 77: 285-287.

Mangialardi, G. J., Jr., R. V. Baker, D. W. Van Doom, B. M. Norman, and R. M. Sutton. 1994. Lint cleaning, pp. 102-119. In W. S. Anthony and W. D. Mayfield [eds.], Cotton ginners handbook. USDA, Agricultural Handbook 503.

McArdle, B. H. 1990. When are rare species not there? Oikos 57: 276-277.

Nelson, J., S. Misra, B. Bennett, and G. Barker. 1999. Gin lint cleaning to maximize producer net returns revisited. Appl. Eng. Agric. 15: 621-626.

Robertson, O. T., D. F. Martin, D. M. Alberson, V. L. Stedronsky, and D. M. McEachern. 1963. Pink bollworm kill with improved gin equipment. USDA-ARS Prod. Res. Rep. No. 73.

Sappington, T. W., A. D. Brashears, M. N. Parajulee, S. C. Carroll, M. D. Arnold, J. W. Norman Jr., and A. E. Knutson. 2004a. Potential for transport of boll weevils (Coleoptera: Curculionidae) to the cotton gin within cotton modules. J. Econ. Entomol. 97: 934-940.

Sappington, T. W., A. D. Brashears, M. N. Parajulee, S. C. Carroll, M. D. Arnold, and R. V. Baker. 2004b. Boll weevil (Coleoptera: Curculionidae) survival through the seed cotton cleaning process in the cotton gin. J. Econ. Entomol. 97: 1323-1329.

Sappington, T. W., A. D. Brashears, M. N. Parajulee, S. C. Carroll, M. D. Arnold, and R. V. Baker. 2004c. Boll weevil (Coleoptera: Curculionidae) survival through cotton gin trash fans. J. Econ. Entomol. 97: 1612-1618. 
Smith, J. W. 1998. Boll weevil eradication: area-wide pest management. Ann. Entomol. Soc. Am. 91: 239-247.

Spurgeon, D. W., and J. R. Raulston. 1998. Diapause induction in subtropical boll weevils, pp. 1019-1025. In Proceedings of the Beltwide Cotton Conferences, 6-10 January, San Diego, CA. National Cotton Council, Memphis, TN.

Spurgeon, D. W., T. W. Sappington, and C. P.-C. Suh. 2003. A system for characterizing reproductive and diapause morphology in the boll weevil (Coleoptera: Curculionidae). Ann. Entomol. Soc. Am. 96: 1-11.
Venette, R. C., R. D. Moon, and W. D. Hutchinson. 2002. Strategies and statistics of sampling for rare individuals. Annu. Rev. Entomol. 47: 143-174.

Willcutt, M. H., and W. D. Mayfield. 1994. Cottonseed handling and storage, pp. 195-214. In W. S. Anthony and W. D. Mayfield [eds.], Cotton ginners handbook. USDA, Agricultural Handbook 503.

Received 22 June 2004; accepted 10 September 2004. 